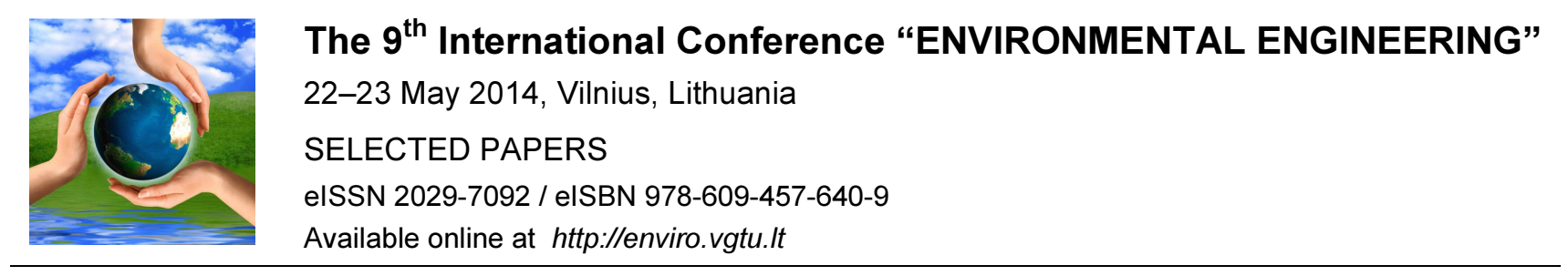

Section: Technologies of Geodesy and Cadastre

\title{
Regarding taxation of excess land property, occupied by industrial facilities
}

\author{
Lesia Vasylivna Melnyk \\ Kyiv National University of Construction and Architecture, 31, Povitroflotsky Avenue, Kyiv-037, 03680 Ukraine
}

\begin{abstract}
An analysis of the domestic legal and regulatory framework for land taxation has been performed. The ratio of industry land within the land resources of Ukraine has been investigated. The legal basis for determination of land plot areas necessary for implementation of industrial activities has been considered. The legal regime of industry land has been investigated. The conclusion of the need for improvement of methods for determining excess areas for taxation purposes has been made.
\end{abstract}

Keywords: industrial facility; excess area; taxation.

\section{Main contents of the work}

According to the Constitution of Ukraine [1], land is national wealth and it should be under special state protection. Solving the problem of exaction of payments for land, under conditions of market-based economy development, has been and remains especially important. The issue of exaction of payments for land is closely related to accounting of land plots, completeness and accuracy of which depends on local governments, authorities and land management agencies.

By today the extremely important question of forming an effective tax system in Ukraine remains unresolved. The problem of taxation must be approached holistically, taking into account both critically assimilated foreign experience and domestic features and distinct perspectives and courses of development. Lack of perspectives, vagueness of priorities, objectives and implementation mechanisms, in circumstances where there are no developed institutions of the democratic, law-governed state and civil society, makes it impossible to build a socially oriented economy in the country.

In the Payments for Land Act of Ukraine [2], which was valid until 01.01.2011, there was a provision which stated that the part of land plots' areas, given to enterprises, institutions and organizations (other than agricultural land), which exceeds the allocation limits, should be taxed above quota. However, this rule did not have a practical implementation, since there is no well-defined mechanism for determining the regulatory area.

Ukraine inherited large industrial facilities from the USSR that have reserved large areas that are redundant and not used in full. The development of methods for determining excess areas, especially for industrial facilities in cities, will optimize land use in localities.

The existing legislation of Ukraine in the sphere of land regulation is not yet fully focused on the issues of payments for land.

The problem lies in the lack of an appropriate mechanism of normative legal and business regulation of determining the required and excess area that is needed for the operation of an industrial facility.

The regulatory area of land under industrial facility is determined according to health standards and regulations II-89-80 "General Layouts for Industrial Enterprises" [3]. There have been changes in technological processes, equipment and the need in some industries altogether since the date of adoption of the document, so the development of approaches that provide a means of calculating the area of land for productive activities is a key issue.

According to Articles 13 and 14 of The Constitution of Ukraine [1], the land lying within the territory of Ukraine is the property of the Ukrainian people and is the main national wealth that is under special state protection. The property right to land is guaranteed. This right is acquired and exercised by the citizens, legal persons and the State only in accordance with the law.

Corresponding author: Lesia Vasylivna Melnyk. E-mail address: lesia_gorpynich@mail.ru http://dx.doi.org/10.3846/enviro.2014.228

(C) 2014 The Author. Published by VGTU Press. This is an open-access article distributed under the terms of the Creative Commons Attribution License, which permits unrestricted use, distribution, and reproduction in any medium, provided the original author and source are credited. 
The use of land in Ukraine is fee-based. Payments for land are levied in the form of land tax or rent, which is determined by the monetary value of this land. Tax amount for the land, the monetary value of which was not estimated, was previously determined in the manner, specified by the Payments for Land Act of Ukraine" [2]. This Law used to define the size and manner of payment for usage of land resources, as well as responsibilities of taxpayers and control over correctness of calculation and collection of land tax. Now the specifics of exaction of payments for land are defined in Chapter XIII of The Tax Code of Ukraine, which entered into force on 01.01.11 [4].

There are differences between the no longer valid Payments for Land Act of Ukraine [2] and the current Tax Code of Ukraine [4], this applies to both design and content of the text.

The Tax Code of Ukraine [4] states that payments for land combine two mandatory payments - land tax and rent for land plots of the state and municipal property.

Land tax is a compulsory payment levied on land plots and land shares owners and permanent land users, and rent for the land plots that are in state and municipal property is a compulsory payment which a tenant pays to a landlord for land usage.

1. In contrast to the Payments for Land Act of Ukraine [2], The Tax Code [4] in addition to concepts such as monetary valuation, tax, tax rate, rent, agricultural land, land for residential and public development, cites a number of other definitions including landowners, taxpayer's liability, state land cadastre data, land users, land plot, land improvements, rail transportation land, forest land, non-forest land, unit of area of taxable land plot, building surrounding grounds, purposiveness of a land plot and so on.

2. A significant difference is observed in the tax rates for the land plots, normative monetary evaluation of which was not carried out. According to the Amendments Being Made to The Tax Code of Ukraine on the Revision of Certain Taxation and Revenue Act of Ukraine from 22.12.2011, № 4235-VI [5], amendments have been made to paragraph 275.1 of Article 275 of The Tax Code: tax rates for the land plots, normative monetary evaluation of which was not carried out, have been increased to 8.9 (Table 1).

The lands of industry, transport, communications, energy, defense and of other purposes are an independent category of lands within the land resources of Ukraine. They cover an area of 223.2 thousand hectares, accounting for $0.4 \%$ of the total area of the state's territory (Fig. 1) [6].

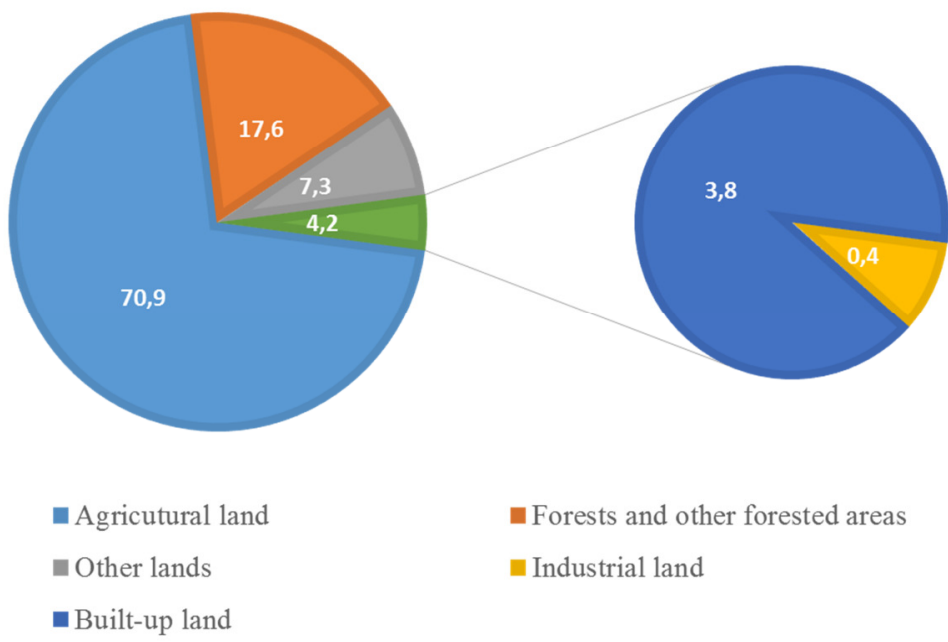

Fig. 1. Land resources of Ukraine as of 01.01.2013

In accordance with paragraph 1 of Article 65 of The Land Code of Ukraine [7], the lands of industry, transport, communications, energy and defense and of other purposes are defined as the lands granted in the prescribed manner to enterprises, institutions and organizations for the corresponding activity.

Their legal regime is determined by regulatory requirements, which are concentrated in The Land Code of Ukraine (Chapter 13) [7] and a number of other regulations. Most of the legal rules, governing the legal regime of these lands, are enshrined in free-standing instruments, devoted mainly to special activities of certain enterprises, institutions and organizations, including The Air Code, The State Border, The Defense of Ukraine, The Transportation, The Communication, The Rail Transport, The Pipeline Transport, The Electric Power Industry and The Road Transport Acts of Ukraine.

The legal regime of all types (subcategories) of the specified lands is based on common principles: national and public importance of the category, which these lands belong to; special tasks of usage of such lands.

The main feature of their legal regime is ensuring of balanced environmentally sustainable land use in the operation of a variety of non-agricultural facilities. As for the features of legal regulation of usage and protection of certain land types that belong to this category, they are based on specifics of their purpose [8]. 


\begin{tabular}{|c|c|c|c|c|c|c|c|c|c|c|c|c|c|}
\hline \multicolumn{2}{|c|}{ 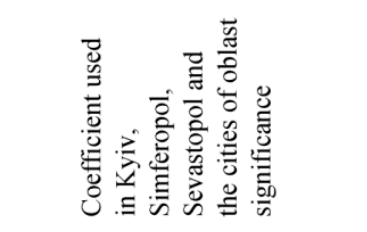 } & & & & & & & $\cong$ & $\stackrel{\Xi}{=}$ & $\stackrel{0}{0}$ & $\mathrm{~N}$ & $\hat{n}$ & m \\
\hline \multirow{2}{*}{ 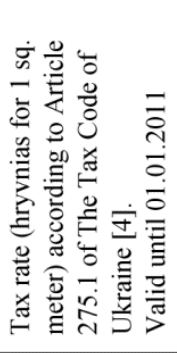 } & 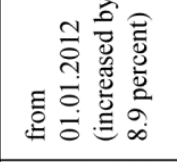 & ¿ֶ. & के & f & & $\begin{array}{c}1 \\
6 \\
0 \\
0\end{array}$ & 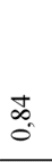 & $\stackrel{m}{-}$ & in & $\stackrel{\infty}{-}$ & $\begin{array}{l}\partial \\
\text { in }\end{array}$ & $\begin{array}{l}\bar{b} \\
i\end{array}$ & $\begin{array}{l}: \\
\stackrel{0}{0}\end{array}$ \\
\hline & 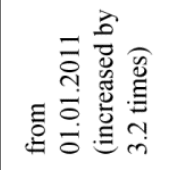 & đ̇ & ले & $\stackrel{f}{0}$ & & 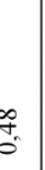 & 응 & 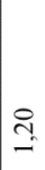 & $\underset{-}{J}$ & $\stackrel{\infty}{\mathscr{0}}$ & $\tilde{\Omega}$ & 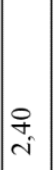 & 赵 \\
\hline \multirow{7}{*}{ 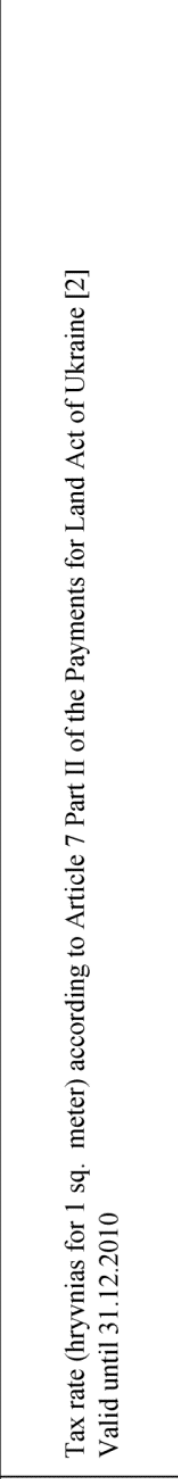 } & 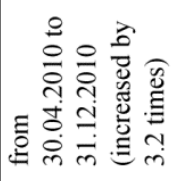 & İ & లై & శี & & $\begin{array}{l}0 \\
0 \\
0 \\
0 \\
0\end{array}$ & $\begin{array}{l}\infty \\
\stackrel{0}{0} \\
0\end{array}$ & $\cong$ & $\underset{-}{J}$ & $\mid$\begin{tabular}{c}
$\infty$ \\
\hdashline \\
\hdashline-1
\end{tabular} & $\tilde{\sigma}$ & i & m. \\
\hline & 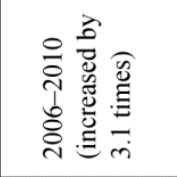 & त̂. & 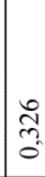 & $\frac{9}{7}$ & & $\begin{array}{l}0 \\
0 \\
0 \\
0\end{array}$ & 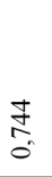 & $\stackrel{8}{=}$ & $\stackrel{\circ}{\stackrel{m}{-}}$ & 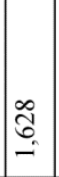 & 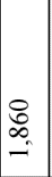 & $\begin{array}{l}\curvearrowright \\
\tilde{N} \\
i\end{array}$ & 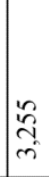 \\
\hline & 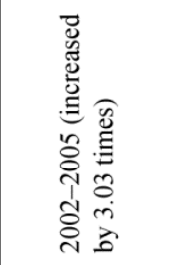 & กิ & כె. & F. & & $\begin{array}{l}f \\
0 \\
0 \\
0\end{array}$ & $\hat{\Omega}$ & $\stackrel{ \pm}{=}$ & $\stackrel{\infty}{\sim}$ & $\stackrel{2}{:}$ & $\underset{\infty}{\infty}$ & $\mid \overrightarrow{\hat{i}}$ & $\frac{\infty}{m}$ \\
\hline & 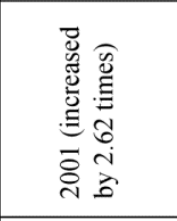 & ్ㅗ & $\begin{array}{l}\infty \\
\text { â } \\
0\end{array}$ & m. & & on & $\begin{array}{l}3 \\
0 \\
0\end{array}$ & $\begin{array}{l}\infty \\
0\end{array}$ & $\stackrel{\infty}{=}$ & 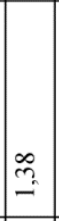 & in & $\stackrel{2}{-}$ & $\stackrel{n}{i}$ \\
\hline & 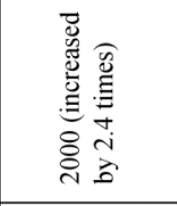 & $\frac{\infty}{0}$ & $\begin{array}{l}\text { กิ } \\
\text { o. }\end{array}$ & तु & & 8 & $\begin{array}{l}0 \\
\text { in } \\
\text { s. }\end{array}$ & $\therefore$ & $\stackrel{\infty}{\stackrel{\circ}{-}}$ & $\stackrel{2}{\sim}$ & 志 & $\stackrel{\infty}{-}$ & 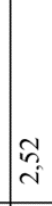 \\
\hline & 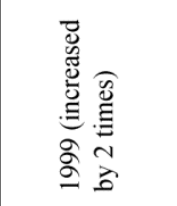 & $\stackrel{2}{0}$ & స̃. & ઼ָ & & $?$ & $\begin{array}{l}\infty \\
0 \\
0 \\
0\end{array}$ & $\stackrel{2}{0}$ & $\hat{o}$ & 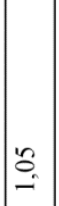 & $\cong$ & $\because$ & $\overline{\mathrm{s}}$ \\
\hline & 总 & م. & $=$ & $\frac{ \pm}{0}$ & & $\frac{n}{6}$ & đ̃ & $\begin{array}{c}\infty \\
\infty \\
0 \\
0\end{array}$ & ?n & $\hat{n}$ & $\stackrel{8}{\circ}$ & $\stackrel{2}{0}$ & $\stackrel{2}{0}$ \\
\hline \multicolumn{2}{|c|}{ 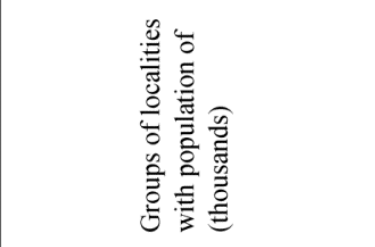 } & 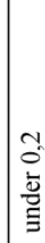 & 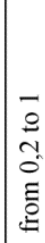 & $\frac{3}{\stackrel{3}{g}}$ & & 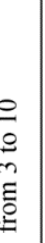 & 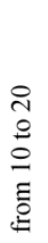 & 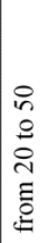 & $\begin{array}{l}8 \\
8 \\
0 \\
0 \\
0 \\
\vdots \\
0 \\
0\end{array}$ & 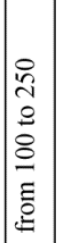 & 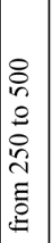 & 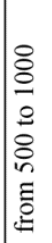 & 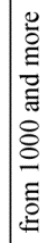 \\
\hline
\end{tabular}


Land plots that belong to this category of land are characterized by a diversified purposiveness and legal regime. Meanwhile, it is agreed under the law in legal doctrine to provide common features of legal regime of land for industry, transport, communications, energy, and defense and for other purposes. In particular:

- all land plots in this category have a special non-agricultural purpose, which allows to compendiously call this category of land in professional literature - lands of special nonagricultural purpose;

- size of relevant plots is determined on the basis of standards, approved in the established procedure (for typical facilities - railways, roads, power lines, airports, pipelines, etc.) or projects, approved in the established procedure (for non-standard facilities - industrial enterprise, etc.) that, however, are also developed in accordance with certain standards. This allows distinguishing such specific feature of land for non-agricultural purposes, as size normalization of relevant plots;

- In most sectors of economy lands are used inefficiently, due to imperfect regulations and low-level design and technical solutions. The regulations of land allotment for the needs of industry, transport and energy are 2.5-2.7 times higher than those accepted in Western European countries.

- internal and external zoning of land for special non-agricultural purposes is carried out. So, for example, sanitary protection zones, where home construction activity and housing is prohibited, are set around potentially harmful objects, and exclusion zones are set around potentially vulnerable facilities, and so on.

- in certain cases, the areas designated for special non-agricultural purposes, may be not assigned as separate plots at all. Specifically it is referred to the land plots designated to locate some linear objects (communications, power lines, and underground pipelines). Although a separate plot of land for the location of such object is not allotted, the location of the object causes significant changes to the regime of the corresponding area, in particular, exclusion and sanitary protection zone is set. The applicable land servitude can be set.

In most cases legislation has no rules for determining legal regime of land plots that concomitantly cover the features of several types of industry, transport, communications, energy, defense lands and lands of other purposes (e.g., land at intersection of line networks).

Formulation of the concept of "industry land" is contained in paragraph 1 of Article 66 of The Land Code of Ukraine: "1. Industrial lands are the lands granted for placement and operation of the main, auxiliary and ancillary buildings of industrial, mining, transport and other enterprises, their access roads, utilities, administrative and residential buildings and other structures" [7].

According to paragraph 3 of Article 66 of The Land Code of Ukraine: "3. Size of land plots provided for these purposes, shall be determined in accordance with the approved in the established procedure state standards and design documentation, and land plots allotment shall be based on the sequence of their development" [7].

Size and internal zoning of land plots of industrial enterprises is defined by project documentation based on sanitary norms and regulations II-89-80 "General Layouts for Industrial Enterprises" [3] that, in particular, establish standards for minimum site development density, which affects the area of land required, allow for functional zoning "based on technological linkages, sanitation and fire protection requirements, cargo turnover and means of transport" (par. 3.3., etc.), determine the configuration of buildings (par. 3.22.), the distance between buildings (paragraphs 3.25., 3.26., Tables 1-4, etc.) and so on.

In particular, par 3.8. of norms and regulations provides for allocation of the following zones on the site of an enterprise:

(a) offsite area (outside a fence or conventional boarders of an enterprise),

(b) production zone,

(c) auxiliary zone,

(d) storage area.

Within a production area the following zones are allocated

(e) civic center,

(f) enterprise grounds,

(g) common objects of auxiliary departments and facilities.

Zoning is allowed to be specified taking into account specific conditions of an enterprise.

External zoning of lands adjacent to industrial enterprises' plots, such as setting sanitary protection zones around enterprises, is carried out on the basis of the State Sanitary Regulations of Planning and Building of Settlements approved by The Ministry of Healthcare of Ukraine from 19.06.1996 № 173 [9] (replaced the Sanitary Norms 245-71 "Sanitary Norms of Design of Industrial Enterprises", approved by the State Committee of the Council of Ministers of the USSR on Construction on $05 / 11 / 1971$ [10]).

There are 5 hazard classes of enterprises that are determined in accordance with the Sanitary Classification of Enterprises, Productions and Constructions (Annex 4 to Regulations [3]) (class I means the most dangerous enterprises, productions and constructions), according to which a sanitary protection zone is from 50 to $3000 \mathrm{~m}$.

The law does not provide for restrictions on a circle of persons who may have industry land on the right of ownership or usage (paragraph 2 of Article 66 of The Land Code of Ukraine [7]).

During the "Soviet era" there was a practice of placement of industrial enterprises on lands that were allocated for the usage by other land users - on railroad and highways precincts and even on agricultural lands (this refers to inter-collective 
farm enterprises). Their land usage was not documented in any way, which nowadays generates multitude conflicts and disagreements [8].

The use of land in Ukraine is fee-based. Payments for land are levied in the form of land tax or rent, which is determined depending on the monetary value of this land.

The part of land plots' areas given to enterprises, institutions and organizations (other than agricultural land), that exceeds the allocation limits, should be used effectively. But there is no well-defined mechanism for determining of the regulatory area for facilities. Solving this problem will increase the rational area of localities and improve the system of land tenure.

\section{References}

[1] Конституція Украӥни , Відомості Верховної Ради України. 1996. №254к/96вр. ст.47 Available from Internet: www.zakon2.rada.gov.ua/laws/show/254к/96-вр

[2] Закон України «Про плату за землю», Відомості Верховної Ради України. 1992. №2535-XII - cт.20 Available from Internet: http://zakon4.rada.gov.ua/laws/show/2535-12

[3] СНиП ІІ-89-80. Генеральные планы промышленных предприятий. М.: Стройиздат, 1981.

[4] Податковий кодекс Украӥни, Відомості Верховної Ради України. 2012. № 2755-VI - ст.621 Available from Internet: http://zakon4.rada.gov.ua/laws/show/2755-17

[5] Закон Украӥни «Про внесення змін до Податкового кодексу Украӥни щооо перегляду ставок деяких податків $і$ зборів», Відомості Верховної Ради України. 2011. №4235-VI.

[6] Available from Internet: www.ukrstat.gov.ua.

[7] Земельний кодекс України, Відомості Верховної Ради України. 2002. N 3-4, ст.27 Available from Internet: http://zakon4.rada.gov.ua/laws/show/2768-14

[8] Мірошніченко, А. М. Правовий режим земель промисловості, транспорту, зв язку, енергетики, оборони та іниого призначення. Ауаilable from Internet: http://www.pandia.ru/text/77/191/15740.php.

[9] Наказ Міністерства охорони здоров'я України від 19.06.1996 № 173

[10]СНиП 245-71. Санитарные нормы проектирования промышленных предприятий, Ведомости Государственного комитета Рады Министров СРСР в делах строительства. 1971. 